\title{
Pengaruh Dukungan Organisasi Menjembatani Faktor Internal dalam Individu ke Intensi Tindakan Whistleblowing
}

\author{
Imanda Firmantyas Putri Pertiwi, Intan Nur Prasasti, Zakky Fahma \\ IAIN Surakarta \\ Imandaf_putri@ymail.com
}

\begin{abstract}
This research aims to provide an overview of how much person's internal factors such as professional commitment, anticipatory socialization and locus of control can affect their intention to perform whistleblowing action when they find fraud within the institution, also how strong is the organization's support in moderating internal factors to the whistleblowing intentions. The method used in this research is Moderated regression analysis (MRA) followed by sub group moderated analysis. The results obtained from this study are proven that professional commitment can significantly improve the whistleblowing intentions, but anticipatory socialization and locus of control despite showing a significant influence, instead it shows negative direction. Organizational support has not been able to take part as a factor that can strengthens or weakens the relationship between the three variables mentioned earlier with the intention of someone to do whistleblowing.
\end{abstract}

Keywords: whistleblowing; professional commitment; anticipatory socialization; locus of control; organizational support

\begin{abstract}
Abstrak
Penelitian ini bertujuan untuk memberikan gambaran mengenai seberapa besar faktor internal dalam diri seseorang seperti faktor komitmen profesional, sosialisasi antisipatif dan locus of control dapat mempengarubi intensi orang tersebut untuk melakukan tindakan whistleblowing, saat menemukan adanya kecurangan didalam lembaga.Juga seberapa kuat dukungan organisasidalam memoderasi faktor internal dengan intensi whistleblowing tersebut. Metode yang digunakan dalam penelitian ini adalab Moderated regression analysis (MRA) yang dilanjutkan dengan analisis moderasi sub kelompok. Hasil yang diperoleh dari penelitian ini adalah komitmen profesional terbukti secara signifikan dapat meningkatkan intensi whistleblowing, namun sosialisasi antisipatif dan locus of control walaupun menunjukkan pengarub yang signifikan, sebaliknya justru menunujukkan arab yang negatif. Dukungan organisasi belum mampu berperan sebagai faktor yang memperkuat ataupun memperlemah hubungan antara ketiga variabel yang disebutkan di awal tadi dengan intensi seseorang untuk melakukan whistleblowing.
\end{abstract}

Kata Kunci: whistleblowing; komitmen profesional; sosialisasi antisipatif; locus of control; dukungan organisasi

Permalink/DOI:http://dx.doi.org/10.18326/infsl3.v11i2.391-408 


\section{Pendahuluan}

Corruption Perception Index (CPI) per 25 Januari 2017 lalu mengeluarkan hasil mengenai indeks korupsi 176 negara di dunia untuk tahun 2016. Indonesia mengalami peningkatan nilai sebesar 1 poin dibandingkan tahun 2015, namun secara peringkat harus rela turun sebesar 2 peringkat. Skor sebesar 37 poin, masih jauh tertinggal jika dibandingkan dengan skor rerata global yang sebesar 43 poin. Apabila disandingkan dengan negara tetangga, Indonesia mampu melampaui capaian Thailand, Filipina, Vietnam, Myanmar dan Kamboja, walaupun harus berlapang dada mengakui ketertinggalan dari Malaysia, Brunei dan Singapura (Toriana \& Thohary, 2017)

Ketertinggalan dari tiga negara tetangga yang peringkatnya jauh diatas Indonesia seperti yang disebutkan diatas berusaha diatasi oleh pemerintah melalui kata kunci reformasi birokrasi. Reformasi Birokrasi yang dicanangkan sejak Pemerintah Indonesia menerbitkan Peraturan Presiden Nomor 80 Tahun 2011 tentang Grand Desain Reformasi Birokrasi Indonesia 2010-2025 dan PERMENPANRB Nomor 20 Tahun 2010 tentang Road Map Reformasi Birokrasi 2010-2014 (n.a, 2016) ini diharapkan dapat memberikan suatu perubahan mendasar pada sistem birokrasi kita dan menjadi angin segar bagi pemberantasan korupsi di Indonesia. Walaupun secara global Indonesia masih tertinggal dalam hal pemberantasan korupsi (Syawawi, 2017), namun secara konsisten upaya peningkatan terus dilakukan (Berry, 2017).

Salah satu upaya yang dilakukan oleh pemerintah dalam rangka reformasi birokrasi adalah dengan menciptakan suatu sistem whistleblowing di segenap jajaran pemerintahan, baik pemerintahan pusat maupun daerah. Berbagai kementerian maupun pemerintah daerah sudah mulai merumuskan aturan resmi mengenai pelaksanaan sistem whistleblowing. Dua subyek dalam penelitian ini juga telah memiliki aturan mengenai pelaksanaan whistleblowing ini. Kementerian Agama melalui Keputusan Menteri Agama Republik Indonesia No.95 Tahun 2014 Tentang Pedoman Pengelolaan Pengaduan Masyarakat dan Whistleblowing di Lingkungan Kementerian Agama, dan Pemerintah Boyolali melalui 
Peraturan Bupati Boyolali No.7 Tahun 2016 tentang Kebijakan Pengawasan di Lingkungan Pemerintah Kabupaten Boyolali Tahun 2016.

Boyolali mendapatkan sorotan beberapa waktu yang lalu dengan adanya kasus ancaman dan ketidakadilan terhadap pelaku whistleblower pada tahun 2004. Tersebutlah Purwanto, seorang guru yang bertugas di Boyolali. Pada tahun 2004, ia mengkritisi secara tertulis kebijakan pendidikan yang berlaku di SMA Bhineka Karya Boyolali. Kritik ini ia sampaikan melalui Forum Komunikasi Guru Boyolali kepada Bupati Boyolali terkait dengan adanya "Tambahan Penghasilan" untuk guru. Perilaku whistleblowing yang dilakukannya berdampak pada dipindahtugaskannya ke SMA Negeri 1 Sambi Boyolali. Namun di sekolah baru ini pun Purwanto melakukan kritik atas kebijakan Komite Sekolah dalam pengelolaan dana komite bersama dengan Kepala Sekolah. Perbuatan whistleblowing yang dilakukan oleh Purwanto ini bukannya tanpa konsekuensi. Purwanto mendapatkan teguran tertulis, ancaman pembunuhan secara terbuka, pencabutan dari tugas fungsional guru, penghentian pembayaran gaji dan terakhir adalah pemecatan dengan hormat tidak atas permintaan sendiri dari pegawai negeri sipil (Awaludin, 2016).

Kementerian Agama juga sempat mendapat perhatian atas kasus whistleblowing yang terjadi di Kementerian Agama Jawa Timur, saat Mohammad Amin Tohari melaporkan kasus dugaan tindak pidana korupsi dalam proyek pembangunan penginapan santri di jalan Juanda, Surabaya, Jawa Timur pada tahun 2014. Bernasib tak berbeda dengan Purwanto, Amin juga diberhentikan sebagai Aparatur Sipil Negara. Suatu akhir yang tragis bagi seorang whistleblower yang melalui laporannya kerugian negara sebesar 2,2M berhasil ditemukan (Rio, 2015).

Kasus ketidakadilan yang terjadi pada pelapor dugaan korupsi atau penyelewengan uang negara seharusnya tidak terjadi apabila sudah ada aturan hukum yang jelas dan tegas, karena pada prinsipnya perilaku seorang whistleblower merupakan prosocial behaviour' yang menekankan untuk membantu pihak lain dalam menyehatkan sebuah organisasi atau perusahaan (Sagara, 2013). 
Tidak mudahnya menjadi seorang whistleblower membuat para peneliti terus menerus mencari tau mengenai faktorfaktor apa sajakah yang dapat mempengaruhi seseorang untuk melakukan tindakan whistleblowing. Karena apabila faktor-faktor tersebut dapat dipenuhi, maka diharapkan para whistleblower dapat bermunculan dan menjadi langkah awal bersihnya birokrasi Indonesia.

Perilaku whistleblowing dapat dipengaruhi dari faktor intern maupun ekstern. Faktor ekstern yang mempengaruhi whistleblower antara lain adalah harapan adanya dukungan lingkungan dan keluarga (Yeoh, 2014, budaya organisasi (Wawo, Asni, \& Nurnaluri, 2015), hadiah berupa materi (Yeoh, 2014)serta keyakinan akan kerahasiaan dan keamanan diri (Kohn et al., 2014). Keberanian, haus akan perhatian, dan sindrom yang tak takut kehilangan apapun demi idealisme adalah beberapa faktor internal yang disampaikan Yeoh ( 2014)

Faktor intern lain yang juga telah diteliti adalah komitmen profesi (Aranya, 1981; Kaplan, 2001), sosialisasi antisipatif (Elias, 2008, Garavan \& Morley, 1997), locus of control (Joneta, 2016; Rotter, 1996; ), ethical judgement (Chiu, 2002) dan ethical climate - benevolence serta ethical climate - principle (Setyawati, Ardiyani, \& Sutrisno, 2015).

Dari banyaknya faktor-faktor yang mempengaruhi seseorang termotivasi untuk menjadi seorang whistleblower penelitian ini hanya membatasi pada faktor komitmen profesi, sosialisasi antisipatif dan locus of control (Prasasti, 2017), serta dukungan organisasi saja, karena keempat faktor tersebut diasumsikan oleh penulis mampu mewakili faktor baik dari dalam diri seseorang itu sendiri, maupun dari luar, secara formal maupun secara informal.

Komitmen profesi menurut Aranya (1981) merupakan suatu kebanggaan serta kecintaan terhadap apapun profesi yang dia jalani, yang meliputi tanggung jawab, hasil yang diperoleh, tujuan serta nilai-nilai dari suatu profesi, akuntan yang berkomitmen terhadap profesinya cenderung untuk melakukan tindakan whistleblowing. Kaplan (2001) menemukan bahwa akuntan yang 
lebih berkomitmen terhadap profesinya memiliki kecenderungan untuk melaporkan pelanggaran.

Elias (2008) menemukan bahwa sosialisasi antisipatif berpengaruh terhadap perilaku whistleblowing. Proses penyesuaian diri dan keyakinan dari kelompok tertentu sebelum masuk dalam lingkungan baru, termasuk dalam lingkungan kerja sejak mereka masih dalam masa pendidikan akan menentukan idealisme mereka pada saat bekerja (Elias, 2008). Garavan \& Morley (1997) menerangkan dalam proses sosialisasi antisipatif akan terbentur ekspektasi terhadap suatu karir, dan antisipasi sikap-sikap, normanorma, serta nilai-nilai dari suatu profesi yang akan dimasukinya, ini merupakan hasil dari pembelajaran yang diterima oleh seorang individu bahkan sebelum hari pertama dia bekerja.

Locus of control adalah tingkat keyakinan individu bahwa hasil (peristiwa yang terjadi dalam kehidupannya) tergantung pada perilaku atau karakteristik pribadi mereka atau dalam artian mereka memiliki pengendalian (Rotter, 1996). Seseorang yang mempunyai keyakinan terhadap diri dan kemampuannya dan memiliki perencanaan yang baik akan karir dan hidupnya menurut (Joneta, 2016) akan cenderung untuk melakukan tindakan whistleblowing. Joneta (2016) menambahkan, ketika individu menilai perbuatan yang dilakukannya benarguna mencegah pelanggaran-pelanggaran terulang dan mengembalikan kepercayaan terhadap informasi yang terpercaya bagi para pengguna laporan keuangan, maka bukan hal yang mustahil untuk melakukan whistleblowing.

Dukungan organisasi tempat seseorang bekerja juga seharusnya memiliki peran didalam menentukan apakah seseorang memiliki motivasi untuk melakukan tindakan whistleblowing atau tidak. Sims \& Keenan (1998) menemukan bahwa dukungan dari supervisor atau atasan memiliki peran yang penting bagi seseorang untuk melakukan atau tidak melakukan tindakan whistleblowing. Sims \& Keenan (1998) menambahkan bahwa bagaimana aturan informal suatu organisasi berjalan juga menentukan bagaimana sikap seorang individu. 
Berdasarkan uraian diatas maka penelitian ini hendak menguji mengenai faktor-faktor yang dapat mempengaruhi niat seseorang untuk melakukan whistleblowing. Faktor-faktor ini dibatasi pada faktor komitmen profesi, sosialisasi antisipatif dan locus of control sebagai variabel bebasnya dan dukungan organisasi sebagai variabel moderasi dengan model pengujian MRA. Dua instansi pemerintahan akan dilibatkan penelitian ini, yaitu Dinas Pemerintah Kabupaten Boyolali dan IAIN Surakarta. Dua instansi tersebut dilibatkan dalam penelitian ini dengan asumsi adanya perbedaan yang terjadi dalam hal sosialisasi mengenai peraturan whistleblowing ini, dimana melalui observasi awal diketahui bahwa di IAIN surakarta, sosialisasi sudah dilakukan bahkan banner mengenai whistleblowing ini juga sudah terpasang di lobbi kantor rektorat, sedangkan di Dinas Pemerintah Kabupaten Boyolali hal tersebut belum dilakukan. Subyek penelitiannya adalah para pegawai yang bertugas di bagian keuangan

\section{LANDASAN TEORI}

\section{Theory of Planned Behavior}

Theory of Planned Behavior bertujuan untuk memprediksi dan memahami dampak dari niat berperilaku, mengidentifikasi strategi untuk merubah perilaku serta menjelaskan perilaku nyata manusia (Kreshastuti, 2014). Menurut Ajzen (1991)1985, 1987, tindakan seseorang yang terencana itu biasanya dipengaruhi oleh tiga hal, yang pertama adalah sikap (attitude), yang kedua adalah norma subyektif (subjective norms), dan yang ketiga adalah kontrol perilaku persepsian (perceive behavior control).

Variabel komitmen profesional memerankan komponen sikap terhadap perilaku. Komitmen profesional digunakan sebagai panduan pemahaman nilai-nilai dan norma untuk mengevaluasi sikap akuntan publik dalam menghadapi suatu pekerjaan. Komitmen terhadap profesi akuntansi membuat seseorang mengetahui apa yang seharusnya dilakukan, dalam hal ini whistleblowing (Wahid, 2014). 
Variabel sosialisasi antisipatif dalam penelitian ini memerankan komponen norma subyektif dalam theory of planned behavior. Sosialisasi antisipatif mengandung anggapan bahwa seseorang yang telah lebih dulu berada dalam lingkungan yang mempunyai persepsi tertentu terhadap suatu profesi, maka saat orang tersebut benar-benar berada dalam profesi tersebut, maka seharusnya dia mempunyai kesiapan yang lebih. Joneta (2016) mengatakan para akuntan yang memiliki sosialisasi antisipatif, seharusnya paham akan pentingnya laporan keuangan bagi para pengguna laporan keuangan, oleh karena itu, mereka lebih memahami tanggung jawab dari profesi akuntansi sehingga akan muncul motivasi untuk melakukan whistleblowing.

Variabel locus of control memerankan komponen kontrol perilaku persepsian. Individu yang percaya bahwa apa yang ia perbuatakan membuahkan hasil sesuai dengan apayang ia harapkan (locus of control internal), begitu pula lingkungan sekitarnya juga akan memberikan respon akan tindakannya sesuai dengan yang ia harapkan (locus of control external), dimana perbuatan baik pasti akan dibalas dengan baik, maka individu tersebut akan cenderung melakukan tindakan whistleblowing ketika mereka menilai perbuatan yang dilakukannya benar (Saud, 2016).

\section{Teori Pertukaran Sosial}

Teori pertukaran sosial menurut Cropanzano dan Mictchell (2005) dalam (Saud, 2016) adalah suatu teori yang menjelaskan bahwa terdapat suatu hubungan antara dua belah pihak yang meningkat dari waktu ke waktu menjadi hubungan yang saling mempercayai, loyal, dan saling berkomitmen selama kedua belah pihak menaati aturan-aturan pertukaran. Pedekatan pertukaran sosial mengintegrasikan keyakinan karyawan tentang bagaimana mereka diperlakukan oleh organisasinya dan bagaimana organisasi berkomitmen kepada mereka (Eisenberger e t a 1 ., 1986). Dengan demikian, jika karyawan percaya bahwa organisasi berkomitmen kepadanya maka karyawan juga akan berkomitmen kepada organisasi (Kaplan, 2001). Teori inilah yang akan diangkat dalam menjelaskan variabel dukungan organisasi. 


\section{Komitmen Profesional dan Whistleblowing}

Sikap yang dimiliki oleh individu akan mempengaruhi persepsinya terhadap tindakan etis (Kaplan, 2001). Brabeck (1984) yang dikutip oleh (Sang, 2009) menambahkan bahwa semakin senior seorang pegawai dalam hal usia dan pengalamannya, lebih cenderung untuk melakukan whistleblowing lebih tinggi, karena pegawai yang lebih berpengalaman memiliki komitmen organisasi yang kuat, dengan demikian mereka lebih cenderung melaporkan kecurangan yang dapat membahayakan kelangsungan hidup organisasi mereka.

$\mathrm{H}_{1}$ : Komitmen profesi seorang karyawan dapat berpengaruh positif terhadap niat untuk melakukan tindakan whistleblowing.

\section{Sosialisasi Antisipatif dan Whistleblowing}

Sosialisasi antisipatif merupakan suatu proses pembentukan ekspektasi atau pandangan serta pendapat terhadap suatu karier, karena selama proses sosialisasi individu mengantisipasi sikapsikap, norma-norma, dan nilai-nilai dari suatu profesi yang akan dimasukinya (Sang, 2009). Sosialisasi antisipatif terdiri dari empat variabel, yakni stereotip sosial, proses pelatihan profesional, proses rekrutmen dan proses seleksi organisasional. Keempat variabel tersebut membentuk pemikiran atau pandangan mengenai jenis pekerjaan yang akan dilakukan dari suatu profesi.

Sosialisasi antisipatif akan membantu seseorang untuk patuh terhadap standar etika di dalam profesi yang akan dijalaninya nanti. Terkait dengan niat whistleblowing yang meliputi keseriusan kasus, tanggung jawab dalam melaporkan kasus kecurangan, dan kerugian yang diakibatkan oleh tindakan pelaporan tersebut, (Spector, 1988) menemukan bahwa semakin tinggi tingkat sosialisasi antisipatif seseorang, maka makin tinggi pula kecenderungan orang tersebut untuk melakukan whistleblowing.

$\mathrm{H}_{2}$ : Sosialiasi antisipatif seorang karyawan dapat berpengaruh positif terhadap niat untuk melakukan tindakan whistleblowing. 


\section{Locus of control dan Whistleblowing}

Locus of control didefinisikan sebagai harapan umum bahwa hasil dalam kehidupan dikendalikan baik oleh tindakan sendiri atau dengan kekuatan lain (Rotter, 1996). Locus of control adalah cara pandang seseorang terhadap suatu peristiwa apakah dia merasa dapat atau tidak dapat mengendalikan peristiwa yang terjadi padanya (Chiu, 2002). Locus of control sebagai suatu ciri watak kepribadian memberikan pengaruh pada pembuatan keputusan dan tingkah laku (Rotter, 1996).

Locus of control terbagi menjadi dua, yaitu locus of control internal dan locus of control eksternal. Individu dengan locus of control internal percaya bahwa peristiwa yang terjadi merupakan akibat dari perilaku atau tindakan mereka sendiri, mereka juga percaya bahwa pengalaman mereka dikendalikan oleh kemampuan atau upaya mereka sendiri(Kreitner, n.d.). Sebaliknya, individu dengan locus of control eksternal mengganggap keberhasilan yang dicapai dikontrol dari keadaan sekitarnya, cenderung percaya bahwa peristiwa yang mereka alami merupakan takdir, nasib, kesempatan, atau keberuntungan semata (Spector, 1988).

Individu dengan locus of control internal lebih puas akan pekerjaannya dibandingkan locus of control eksernal (Spector, 1988). Atas dasar itulah variabel locus of control dalam penelitian ini dikaitkan dengan niat seorang individu untuk melakukan whistleblowing. Hipotesis yang dapat dibentuk dari uraian diatas adalah sebagai berikut:

$\mathrm{H}_{3}$ : Locus of control seorang karyawan dapat berpengaruh positif terhadap niat untuk melakukan tindakan whistleblowing.

\section{Dukungan Organisasi dan Whistleblowing}

Miceli and Near (1985) menemukan bahwa pada organisasi yang memberikan dukungan kepada karyawannya, maka perilaku karyawan dalam hal whistleblowing adalah memiliki kecenderungan untuk melakukan whistleblowing internal. Pelanggaran akan dilaporkan kepada kepada atasan yang lebih tinggi, dan apa yang 
dilaporkan pun cenderung menyangkut pelanggaran-pelanggaran "kecil". Sementara bagi organisasi yang dukungan terhadap perilaku whistleblowing nya kecil atau bahkan tidak ada, maka whistleblower cenderung untuk melaporkan pelanggaran kepada pihak eksternal dan untuk pelanggaran-pelanggaran yang sifatnya fatal.

Saud (2016) menemukan bahwa dukungan organisasi berpengaruh dalam intensi untuk mengungkapkan kecurangan. Implikasi dari penelitian Saud (2016) adalah sistem whistleblowing akan efektif jika seluruh elemen dari organisasi, mulai dari level terendah hingga level tertinggi mendukung dan melindungi karyawan yang ingin mengungkapkan kecurangan yang terjadi di bagiannya.

Lebih lanjut, Arikunto (1998) menyimpulkan bahwa ketika seseorang meyakini bahwa tidak ada hambatan dan memiliki kesempatan besar untuk melaporkan tindakan kecurangan, maka semakin besar pula niat seseorang tersebut untuk melakukan tindakan whistleblowing. Terlebih jika individu tersebut merasa bahwa organisasi mendukung dan memberikan perlindungan. Berdasarkan simpulan ini diharapkan melalui penelitian ini akan ditemukan bukti bahwa dukungan organisasi merupakan variabel yang dapat memperkuat intensi karyawan untuk melakukan whistleblowing.

$\mathrm{H}_{4}$ : Dukungan organisasi memperkuat pengaruh antara komitmen profesi seorang karyawan dengan niatnya untuk melakukan tindakan whistleblowing.

$\mathrm{H}_{5}$ : Dukungan organisasi memperkuat pengaruh antara sosialisasi antisipatif seorang karyawan dengan niatnya untuk melakukan tindakan whistleblowing.

$\mathrm{H}_{6}$ : Dukungan organisasi memperkuat pengaruh antara locus of control seorang karyawan dengan niatnya untuk melakukan tindakan whistleblowing. 


\section{Metode Penelitian}

Penelitian ini merupakan penelitian dengan menggunakan metode kuantitatif. Populasi dalam penelitian ini adalah seluruh dinas, kantor, dan SKPD yang ada di Pemerintahan Kabupaten Boyolali, terdapat 9 dinas, 3 kantor, dan 8 SKPD dengan total kurang lebih 100 staf dan kepala bidang keuangan serta seluruh fakultas dan lembaga yang ada di IAIN Surakarta dengan total kurang lebih 65 staf dan kepala bidang keuangan.

Pemilihan sampel dalam penelitian ini didasarkan pada metode convenience sampling, yaitu dengan mengambil sample yang memudahkan peneliti, dalam artian, responden yang akan diberikan kuesioner harus dapat ditemui, bersedia dan bersungguhsungguh dalam pengisian kuesioner. Teknik pengumpulan data yang digunakan dalam penelitian ini adalah dengan angket (Kuesioner) dan in depth interview (wawancara yang mendalam).

\section{Teknik Analisis Data}

Penelitian ini menggunakan teknik analisis Moderated Regression Analysis (MRA), melalui metode MRA ini akan diketahui, apakah variabel dukungan organisasi merupakan variabel pure moderator, quasi moderator, predictor ataukah bomologizer moderator. Apabila ternyata merupakan variabel pure moderator maka selanjutnya akan dilakukan metode analisis Pure Moderator Analysis (PMA), bila quasi moderator maka dilanjutkan dengan metode MRA, bila predictor maka cukup dipecahkan dengan regresi linier berganda dan bila homologizer maka harus dilakukan metode analisis sub-groups.

$$
\begin{gathered}
\text { Klasifikasi Variabel Moderasi } \\
\mathrm{Y}=\mathrm{b} 0+\mathrm{b} 1 \mathrm{X}+\mathrm{b} 2 \mathrm{M}+\mathrm{b} 3 \mathrm{X}^{*} \mathrm{M}
\end{gathered}
$$

Analisis sub kelompok digunakan untuk mengidentifikasi ada tidaknya jenis moderator Homologizer. Analisis ini dilakukan dengan memecah sample menjadi dua sub kelompok atas dasar variabel ketiga yaitu variabel yang dihipotesiskan sebagai moderator. Pengelompokan yang dilakukan adalah secara kualitatif, yaitu berdasarkan perbedaan subyek, yaitu antara IAIN Surakarta dan 
SKPD Boyolali, dengan asumsi ada tidaknya dukungan organisasi. Ada tidaknya dukungan organisasi akan dinilai tidak berdasarkan kuesioner melainkan berdasarkan wawancara mendalam dengan beberapa orang responden dari dua lembaga yang berkaitan.

\section{Analisis}

Komitmen professional berpengaruh terhadap perilaku whitleblowing.

Hasil penelitian menunjukkan bahwa variabel komitmen professional mempunyai nilai $\beta$ sebesar 0.317 dengan nilai probabilitas sebesar 0,000 berarti lebih kecil dari 0,05 maka $\mathrm{Ho}_{1}$ ditolak dan $\mathrm{Ha}_{1}$ diterima, yang artinya variabel komitmen professional mempunyai pengaruh positif yang signifikan terhadap perilaku whistleblowing.

Hal ini dapat diartikan bahwa semakin tinggi tingkat komitmen professional maka meningkatkan intensi untuk melakukan tindakan whistleblowing, begitu pula sebaliknya semakin rendah tingkat komitmen professional maka menurunkan intensi untuk melakukan tindakan whistleblowing. Temuan ini sejalan dengan hasil penelitian yang dilakukan oleh Jalil (2014), mengungkapkan bahwa seseorang dengan komitmen professional yang tinggi, mempunyai kecenderungan dalam melakukan prilaku whistleblowing dibandingkan dengan seseorang dengan komitmen professional yang rendah. Elias (2008) juga mengungkapkan adanya hubungan positif dan pengaruh yang signifikan antara komitmen profesional dengan kemungkingan seseorang untuk melakukan whistleblowing.

Komitmen profesional sebagai suatu kecintaan yang dibentuk oleh seorang individu pada profesinya, meliputi sesuatu yang dipercaya, sesuatu yang diterima, tujuan dan nilai-nilai dari suatu profesi, karena profesi seseorang merupakan bagian utama dalam hidup mereka dan komitmen profesional memiliki implikasi penting pada level individual maupun organisasional. Seseorang yang mempunyai komitmen yang tinggi terhadap profesinya cenderung menginginkan profesinya dijalankan sesempurna mungkin, sehingga apabila terjadi kesalahan yang dilakukan orang lain terkait dengan profesi tersebut maka keinginan tindakan tertentu akan dilakukannya demi profesinya itu, termasuk diantaranya menjadi whistleblower. 
Sosialisasi antisipatif berpengarub terhadap perilaku whitleblowing.

Hasil penelitian menunjukkan bahwa variabel sosialisasi antisipatif mempunyai nilai $\beta$ sebesar -0.495 dengan nilai probabilitas sebesar 0,000 berarti lebih kecil dari 0,05 maka $\mathrm{Ho}_{2}$ ditolak dan $\mathrm{Ha}_{2}$ diterima, yang artinya variabel sosialisasi antisipatif mempunyai pengaruh negatif yang signifikan terhadap perilaku whistleblowing.

Artinya dengan sosialisasi antisipatif yang semakin tinggi berdampak pada intensi melakukan whistleblowing yang semakin rendah. Sosialisasi antisipatif mengacu pada proses sosialisasi di mana seseorang "berlatih" untuk posisi masa depan, pekerjaan, dan hubungan sosial. Hasil penelitian ini tidak dapat mendukung hasil penelitian yang dilakukan oleh Elias (2006) yang mengungkapkan bahwa seseorang dengan sosialisasi antisipatif tinggi, mempunyai kecenderungan dalam melakukan tindakan whistleblowing dibandingkan dengan seseorang dengan sosialisasi antisipatif yang rendah.

Sulaiman (2003) dalam Merdikawati \& Prastiwi (2012) menjelaskan bahwa apabila sosialisasi antisipatif berpengaruh terhadap whistleblowing maka hal tersebut merupakan indikasi proses transfer pengetahuan yang diterima oleh responden saat masih menempuh pendidikan berjalan cukup baik.

Kaitannya dengan variabel whistleblowing dapat diindikasikan walaupun responden cukup memahami pentingnya melakukan tindakan whistleblowing apabila menemukan tindak kecurangan yang terjadi. Akan tetapi, dengan lingkungan yang kurang mendukung terlaksananya perilaku whistleblowing membuat whistleblower berfikir ulang untuk melakukan tindakan tersebut untuk menjamin kelangsungan masa kerjanya dan keselamatan hidupnya.

Hasil penelitian ini tidak seirama denga hasil penelitian yang dilakukan oleh (Chiu, 2002) yang mengungkapkan bahwa proses sosialisasi antisipatif dapat membentuk ekspektasi terhadap suatu karir, karena selama proses sosialisasi individu mengantisipasi sikap, norma dan nilai-nilai dari suatu profesi.

Pengaruh negatifyang dihasilkan dalam penelitian ini barangkali dapat dijelaskan dengan suatu alasan, bahwa seseorang yang justru telah lebih banyak mengetahui mengenai profesi akuntan ataupun keuangan pada saat sebelum memasuki profesi tersebut, menyadari 
bahwa profesi ini rawan dengan kesalahan baik yang disengaja maupun yang tidak disengaja. Pun rawan dengan penggelapan dan penyalahgunaan kekuasaan. Pemahaman semacam inilah yang di kemudian hari memunculkan suatu pemakluman terhadap kesalahan maupun penyelewengan yang terjadi di dalam profesi mereka.

\section{Locus of control berpengarub terhadap perilaku whitleblowing.}

Hasil penelitian ini menunjukkan bahwa variabel locus of control mempunyai nilai $\beta$ sebesar $-0,128$ dengan nilai probabilitas sebesar 0,018 berarti lebih kecil dari 0,05 maka $\mathrm{H}_{3}$ diterima dan $\mathrm{HO}_{3}$ ditolak, yang artinya variabel locus of control mempunyai pengaruh negatif yang signifikan terhadap perilaku whistleblowing. Hal ini dapat diartikan semakin tinggi tingkat locus of control maka menurunkan intensi untuk melakukan tindakan whistleblowing.

Hasil penelitian ini mendukung hasil penelitian yang dilakukan oleh (Chiu, 2002) yang menyatakan bahwa interaksi antara whistleblowing judgement dan locus of control terhadap intensi untuk melakukan whistleblowing ditemukan signifikan. Namun penelitian ini bertentangan dengan penelitian (Budriyanto, 2013) mengungkapkan bahwa auditor dengan locus of control tidak memiliki pengaruh terhadap intensi melakukan whistleblowing.

Individu yang memiliki locus of control internal maupun eksternal seharusnya meyakini bahwa tindakan yang baik akan menghasilkan hasil yang baik pula. Namun dalam kaitannya dengan whistleblowing, telah banyak fakta yang mereka ketahui dan hadapi, bahwa di masa lalu, para pelaku whistleblowing telah sedemikian rupa mendapatkan ketidakadilan. Sehingga fakta ini seakan mematahkan keyakinan dalam diri mereka akan suatu hukum bahwa "tindakan yang baik akan mendapatkan hasil yang baik".

Keyakinanakan hukum "tindakanyangbaikakan mendapatkan hasil yang baik" diatas justru dimaknai oleh mereka dengan logika seperti ini. Bahwa orang yang melakukan penyelewengan nantinya akan dengan sendirinya mendapatkan balasan yang setimpal dari alam tanpa perlu ada seseorang yang melaporkan ataupun membalas tindakan tercela tersebut. Sehingga mereka merasa bahwa bersikap pasif saja sudah merupakan tindakan yang benar. 
Dukungan organisasi bukan merupakan faktor yang dapat memperkuat ataupun memperlemah intensi karyawan dalam melakukan whistleblowing. Temuan ini sejalan dengan Budriyanto (2013) yang menyatakan tidak terdapat bukti bahwa dukungan organisasi memliki dampak terhadap perilaku whistleblowing. Tindakan whistleblowing seringkali dilakukan oleh orang-orang yang memang berkomitmen tinggi, tanpa mempedulikan apakah organisasi tempatnya berada memberikan dukungan terhadap tindakannya atau tidak.

\section{Kesimpulan}

Berdasarkan hasil penelitian yang telah didapatkan, maka dapat disimpulkan bawah Komitmen professional berpengaruh positif dan signifikan terhadap perilaku whistleblowing. Hal ini berarti ketika individu mempunyai komitmen terhadap profesinya, maka ia akan senantiasa melakukan hal-hal yang tidak bertentangan dengan norma dan etika yang ada dan berusaha untuk melindungi profesinya dari tindakan-tindakan yang tidak bertanggungjawab. Hasil penelitian ini konsisten dengan penelitian yang dilakukan oleh Jalil (2014).

Sosialisasi antisipatif berpengaruh negatif dan signifikan terhadap perilaku whistleblowing. Hal ini berarti apabila staff keuangan IAIN Surakarta dan SKPD Boyolali mempunyai tingkat sosialisasi antisipatif yang semakin tinggi justru berdampak pada intensi melakukan whistleblowing yang semakin rendah.

Pemahaman responden yang cukup mengenai pentingnya melakukan tindakan whistleblowing apabila menemukan tindak kecurangan yang terjadi saja tidak cukup dalam menentukan prilaku mereka untuk menjadi whistleblower. Pemahaman atau pengetahuan tidak akan berarti apa-apa tanpa adanya komitmen yang kuat karena tindakan tersebut akan berdampak pada menjamin kelangsungan masa kerjanya dan keselamatan hidupnya. Dan justru terkadang pemahaman dan pengetahuan mengenai profesi akuntan atau keuangan ini menimbulkan satu pemakluman akan kesalahan yang terjadi di dalam profesi tersebut. Hal inilah yang menurunkan intensi mereka untuk melakukan whistleblowing. 
Locus of control berpengaruh negatif terhadap perilaku whistleblowing. Kaitannya dengan pengaruh negatif locus of control terhadap intensi untuk melakukan whistleblowing adalah keyakinan akan hukum "tindakan yang baik akan mendapatkan hasil yang baik" justru dimaknai dengan suatu logika bahwa orang yang melakukan penyelewengan nantinya akan dengan sendirinya mendapatkan balasan yang setimpal dari alam tanpa perlu ada seseorang yang melaporkan ataupun membalas tindakan tercela tersebut. Sehingga mereka merasa bahwa bersikap pasif saja sudah merupakan tindakan yang benar.

Dukungan organisasi tidak mampu memoderasi hubungan antara komitmen profesional, sosialisasi antisipatif, locus of control terhadap whistleblowing. Tindakan whistleblowing seringkali dilakukan oleh orang-orang yang memang berkomitmen tinggi, tanpa mempedulikan apakah organisasi tempatnya berada memberikan dukungan terhadap tindakannya atau tidak.

\section{Daftar Pustaka}

Ajzen, I. (1991). The theory of planned behavior. Orgnizational Behavior and Human Decision Processes, 50, 179-211. https://doi. org/10.1016/0749-5978(91)90020-T

Aranya, N. et. al. (1981). Professional An Examination Of Commitment In Public Accounting *, 6(4), 271-280.

Arikunto, S. (1998). Manajemen Penelitian. Jakarta: Rineka Cipta.

Awaludin, A. (2016). Perlindungan Hukum bagi Aparatur Sipil Negara dalam Menyingkap Korupsi. Retrieved from http://obsessionnews. $\mathrm{com} /$ perlindungan-hukum-bagi-aparatur-sipil-negara-dalammenyingkap-korupsi/

Berry. (2017). Reformasi Birokrasi Dorong Indeks Persepsi Korupsi Indonesia Membaik. Retrieved from http://jpp.go.id/politik/ hukum/301801-reformasi-birokrasi-dorong-indeks-persepsikorupsi-indonesia-membaik

Budriyanto, E. (2013). Pengaruh Aspek Kejelasan, Kesesuaian, Dukungan dan dampak Terhadap Tindakan Pegawai Ketika Menemukan Pelanggaran Etika. Universitas Gajah Mada.

Chiu, R. K. (2002). Ethical judgement, locus of control, and whistleblowing intention: a case study of mainland Chinese MBA students. Managerial Auditing Journal, 17(9), 581-587. https://doi. org/10.1108/02686900210447588 
Elias, R. Z. (2006). The impact of professional commitment and anticipatory socialization on accounting students' ethical orientation. Journal of Business Ethics, 68(1), 83-90. https://doi.org/10.1007/s10551-006-9041-5

Elias, R. Z. (2008). Auditing students' professional commitment and anticipatory socialization and their relationship to whistleblowing. Managerial Auditing Journal, 23(3), 283-294. https://doi. org/10.1108/02686900810857721

Garavan, T. N., \& Morley, M. (1997). The Socialization of High-potential Graduates Into The Organization: Initial Expectations, Experiences and Outcomes. Journal of Managerial Psychology, 12(2), 118-137. https://doi.org/10.1108/02683949710164208

Joneta, C. (2016). Pengaruh Komitmen Profesional dan Pertimbangan Etis Terhadap Intensi Melakukan Whistleblowing: Locus of Control Sebagai Variabel Moderasi. JOM Fekon, 3(1), 735-748.

Kaplan, S. E. and S. M. W. (2001). An Examination of Auditor s Reporting Intentions when Another Auditor is offered Client Employment. Auditing: A Journal of Practice \& Theory, 20(1), 45-63.

Kohn, S. M., Llp, C., Kohn, M. D., Colapinto, D. K., Wilmoth, M. J., Whistleblower, N., ... Chapman, K. (2014). The Importance of Whistleblower Rewards In Combating International Corruption. National Whistleblowers Center.

Kreitner, R. and A. K. (n.d.). Organizational Behavior. Seventh Edition. Mc. Graw-Hill. International Edition. New York. International Edition. 13th Edition. Upper Saddle River. New Jersey 07458.

Kreshastuti, D. K., \& Prastiwi, A. (2014). Analisis Faktor-Faktor Yang Mempengaruhi Whistleblowing ( Studi Empiris pada Kantor Akuntan Publik di Semarang ). Diponegoro Journal of Accounting, 3(2), 1-13.

Merdikawati, R., \& Prastiwi, A. (2012). Hubungan Komitmen Profesi dan Sosialisasi Antisipatif Mahasiswa Akuntansi dengan Niat Whistleblowing. Diponegoro Journal of Accounting, 1(1), 1-12.

n.a. (2016). Hambatan dan Tantangan Reformasi Birokrasi. Retrieved from http://pemerintah.net/hambatan-dan-tantangan-reformasi-birokrasi/

Prasasti, I. N. (2017). Komitmen Profesional, Sosialisasi Antisipatif dan Locus of Control: Pengarubnya Terhadap Perilaku Whistleblowing (Studi Kasus Pada Staff Keuangan Dinas Pemerintahan Kabupaten Boyolali).

Rio. (2015). Soal Dugaan Korupsi Penginapan Santri, Pejabat Kemenag Jatim Diminta Jujur. Retrieved from http://www.bisnissyariah. co.id/2015/09/soal-dugaan-korupsi-penginapan-santri-pejabatkemenag-jatim-diminta-jujur/ 
Rotter, J. B. (1996). Generalized expectancies for internal versus external control of reinforcement. Psychological Monographs, 80(1), 609.

Sagara, Y. 2013. Profesionalisme internal auditor dan intensi melakukan whistleblowing. Jurnal Liquidity, 2(1), 34-44.

Sang, K. et. al. (2009). Anticipatory socialisation amongst architects: a qualitative examination. Education + Training, 51(4), 309-321. https://doi.org/10.1108/00400910910964584

Saud, I. M. (2016). Pengaruh Sikap dan Persepsi Kontrol Perilaku Terhadap Niat Whistleblowing Internal-Eksternal dengan Persepsi Dukungan Organisasi Sebagai Variabel Pemoderasi. Jurnal Akuntansi Dan Investasi, 17(2), 209-219. https://doi.org/10.18196/ jai.2016.0056.209-219

Setyawati, I., Ardiyani, K., \& Sutrisno, R. C. (2015). Faktor-faktor yang Mempengaruhi Niat untuk Melakukan Whistleblowing Internal (The Factors Influencing Internal Whistleblowing Intentions). Jurnal Ekonomi Dan Bisnis, 17(September), 22-33.

Sims, R. L., \& Keenan, J. P. (1998). Predictors and of External Whistleblowing: Intrapersonal Organizational Variables. Journal of Business Ethics, 17(4), 411-421.

Spector, P. E. (1988). Development of the work locus of control scale. Journal of Occupational Psychology, 61(4), 335-340.

Sugiyono. (2012). Statistika Untuk Penelitian Kuantitatif. Bandung: Alfabeta. Syawawi, R. (2017). Perlambatan Pemberantasan Korupsi. Retrieved from http:// www.antikorupsi.org/id/content/perlambatan-pemberantasan-korupsi

Toriana, L., \& Thohary, W. (2017). Corruption Perceptions Index 2016. Retrieved from http://www.transparency.org/news/feature/ corruption_perceptions_index_2016

Wahid, B. (2014). Analisis komitmen profesional dan sosialisasi antisipatif serta hubungannya dengan Whistleblowing. Joumal Al-Mizan, 1O(1), 152-168.

Wawo, A. B., Asni, N., \& Nurnaluri, S. (2015). The Influence of Organizational Culture, Ethical Awareness and Experience to Ethical Judgments AuditorThrough Professional Commitment ( Study at Inspectorate Sub-Province of Bombana ). The International Journal of Engineering and Science, 4(12), 15-25.

Yani Jalil, F. (2014). Pengaruh Komitmen Profesional Dan Sosialisasi Antisipasif Mahasiswa Audit Terhadap Perilaku Whistleblowing, 4(2), 198-209.

Yeoh, P. (2014). Whistleblowing: Motivations, Corporate self-regulation, And the law. International Journal of Law and Management, 56(6). https://doi.org/10.1108/IJLMA-06-2013-002 